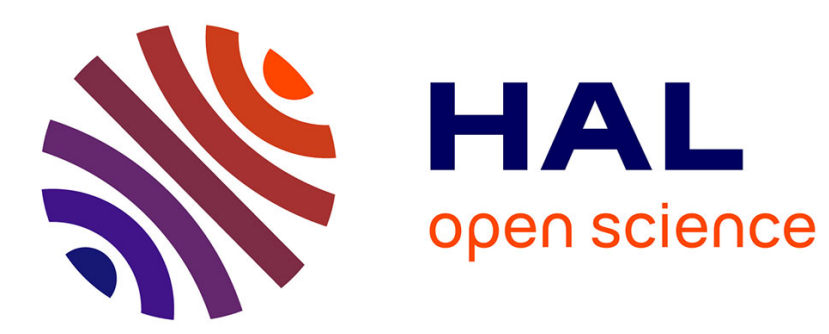

\title{
Port marketing as manifestation of sustainable marketing in a $\mathrm{B} 2 \mathrm{~B}$ context
}

Alexandre Lavissiere, Tibor Mandják, Julian Hofmann, Laurent Fedi

\section{To cite this version:}

Alexandre Lavissiere, Tibor Mandják, Julian Hofmann, Laurent Fedi. Port marketing as manifestation of sustainable marketing in a B2B context. Journal of Business and Industrial Marketing, 2019, 35 (3), pp.524-536. 10.1108/JBIM-12-2018-0409 . hal-02904470

\section{HAL Id: hal-02904470}

\section{https://hal-normandie-univ.archives-ouvertes.fr/hal-02904470}

Submitted on 12 Nov 2020

HAL is a multi-disciplinary open access archive for the deposit and dissemination of scientific research documents, whether they are published or not. The documents may come from teaching and research institutions in France or abroad, or from public or private research centers.
L'archive ouverte pluridisciplinaire HAL, est destinée au dépôt et à la diffusion de documents scientifiques de niveau recherche, publiés ou non, émanant des établissements d'enseignement et de recherche français ou étrangers, des laboratoires publics ou privés. 


\section{Smart Proof System Instructions}

It is recommended that you read all instructions below; even if you are familiar with online review practices.

Using the Smart Proof system, proof reviewers can easily review the PDF proof, annotate corrections, respond to queries directly from the locally saved PDF proof, all of which are automatically submitted directly to our database without having to upload the annotated PDF.

$\checkmark$ Login into Smart Proof anywhere you are connected to the internet.

$\checkmark$ Review the proof on the following pages and mark corrections,

Annotations changes, and query responses using the Annotation Tools.

Note: Editing done by replacing the text on this PDF is not permitted with this application.

$\checkmark$ Save your proof corrections by clicking the "Publish Comments" button.

Publish Comments

Corrections don't have to be marked in one sitting. You can publish comments and log back in at a later time to add and publish more comments before you click the "Complete Proof Review" button below.

$\checkmark$ Complete your review after all corrections have been published to the server by clicking the "Complete Proof Review" button below.

Before completing your review....

Did you reply to all author queries found in your proof?

Did you click the "Publish Comments" button to save all your corrections? Any unpublished comments will be lost.

Note: Once you click "Complete Proof Review" you will not be able to add or publish additional corrections.

Complete Proof Review 


\title{
Port marketing as manifestation of sustainable marketing in a B2B context
}

Alexandre Lavissier

Institut Portuaire d'Enseignement et de Recherche, École de Management de Normandie, Caen, France

Tibor Mandják

École de Management de Normandie, Le Havre, France

Fulian Hofmann

Department of Marketing, École de Management de Normandie - Campus du Havre, Le Havre, France, anc

Laurent Fedi

Kedge Business School, Marseille, France

\begin{abstract}
Purpose - Previous literature dealing with sustainable marketing in a B2B context is mostly limited to spot measures on an environmental, economic or social layer. Thus, the purpose of this paper is to exemplify how seaports as powerful economic business networks can facilitate multilayered sustainability.

Design/methodology/approach - The authors integrate multiple case studies to pursue an inductive research approach to derive general patterns based on empirical observations.

Findings - Operationalizing the concept of a port community enables the authors to show how seaports not only facilitate multi-layered sustainability but also mutually interact. Hence, port sustainability can be achieved through and by a port community.

Research limitations/implications - The conceptualization of the interplay between port community and multi-layered sustainability contributes to the business and industrial marketing literature in general and to the yet hitherto scarce port marketing literature in particular. Future research should go beyond this initial conceptualization by gathering further empirical research.

Practical implications - The study outlines how strengthening interactions among port management stakeholders (i.e. business and non-business actors such as port authorities and policymakers) might lead to higher economic success and societal welfare by pooling yet hitherto independent resources.

Originality/value - To the best of the authors' knowledge, this is the first study to define how the concept of a holistic port community can facilitate sustainability acted out on its three pillars and how both concepts interact.
\end{abstract}

Keywords Sustainability, Business-to-business marketing, Networks, Port (seaport), Harbor, Port community, Port marketing

Paper type Conceptual paper

\section{Introduction}

An increasing societal awareness puts enormous attention on sustainability as triggered through sustainable business models. Sustainable business models can be conceptualized by successfully integrating different dimensions of a company's embeddedness by balancing environmental, economic and social forces or pillars (Daly and Cobb, 1999). To showcase the importance for companies to successfully integrate these dimensions we refer to (sea)ports as an important (exemplary) network-based business-to-business (B2B) industry. According to the aforementioned three forces, ports:

1 act as important facilitators of (sustainable) economic growth;

The current issue and full text archive of this journal is available on Emerald Insight at: www.emeraldinsight.com/0885-8624.htm

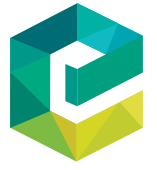

Journal of Business \& Industrial Marketing

(C) Emerald Publishing Limited [ISSN 0885-8624]

[DOI 10.1108/JBIM-12-2018-0409]
2 while (sustainably) integrating social dimensions; and

3 striving for (sustainable) environmental development.

However, integrating those different forces encompasses severe complexity for companies concerned to achieve overall sustainability. Such complexity arises because of the necessity of the companies' interconnectedness. For companies themselves as well as for other actors in such networks it is a crucial criterion to develop, maintain, and shape their relationships to ensure success in the long run as well as to contribute to the society as a whole.

The tremendous macroeconomic relevance of ports exemplifying strong companies' interconnectedness in general is evidenced, for instance, by the fact that more than 70 per cent of global trade by value is handled by ports (Shi and Li, 2017). Among different industries, transportation and logistics are often targeted for their greenhouse gas emissions (GHG) and their capacity to shape (polluting) intercontinental supply

Received 30 December 2018

Revised 13 July 2019

Accepted 25 July 2019 
chains. Intercontinental supply chains are heavily centered on seaports. Ports are an interface of globalization, a node of concentration of all modes of transportation, and also a development tool for policymakers.

Previous literature dealing with sustainability in the context of ports has primarily addressed "green port" initiatives (Acciaro et al., 2014; Chen et al., 2019; Cullinane and Cullinane, 2019; Tseng and Pilcher, 2019; Bergqvist and Monios, 2019) or responsible supply chains (Aguinis and Glavas, 2012; Carbone et al., 2012; Peloza and Shang, 2011). Thus, previous literature dealing with green ports is primarily dealing with single spot measure, whereas literature dealing more holistically with sustainability in a B2B context is scarcer.

We try to overcome this existing shortcoming by using inductive reasoning based on three cases to show how ports can achieve multi-layered sustainability based on its environmental, economic and social pillars. We contribute to the literature at the interface between business and industrial marketing, multifaceted sustainability of business models and port marketing - as an important network-driven B2B concept - as follows. Based on our empirical-qualitative case-method approach, we conceptualize for the first time the concept of "port community" that extends the classical representation of ports in the B2B literature. Moreover we elaborate on to what extend the concepts of sustainability and port community are interrelated. Thus, we address the following two research questions:

RQ1. How to conceptualize port community to characterize the relationship between ports and sustainability?

$R Q 2$. Is a port community helping to move from green ports to sustainable ports?

The paper is structured as follows. In Section 2, we derive our conceptual framework by reviewing thoroughly the underlying literature. In Section 3, we briefly introduce our methodological approach before moving forward to the description and analysis of our three cases in Section 4. In Section 5, we integrate the findings based on all cases to answer our initially raised research questions. Finally, in Section 6, we derive implications for researchers and managers alike and raise implications of our approach that offer avenues for further research.

\section{Conceptual framework}

The literature review is structured according to three main subsections. First, we introduce the theoretical backbone of our case method approach. Namely, we elaborate on the extensive network approach (Aarikka-Stenroos and Ritala, 2017; Aarikka-Stenroos et al., 2014, 2017) expanding business network theory (Håkansson et al., 2009). Considering the complexity of the relationships among port actors (Dooms, 2019; Parola and Maugeri, 2013), authors assume that the theory of business networks, the Actors, Resources and Activities (ARA) model (Håkansson and Snehota, 1995), and the extensive network approach (Aarikka-Stenroos et al., 2017) sound appropriate to analyze interconnections among port actors and associated activities and resources involved in a port community. Second, we will briefly recap literature related to any marketing management activity concerning ports ("port marketing"). Third, we will underline the challenges ports as business networks are facing to achieve sustainability.

\subsection{The extensive network approach facilitating B2B marketing of ports}

Based on the fundamental Industrial Marketing and Purchasing Group's (IMP) approach (Håkansson and Snehota, 1995; Håkansson et al., 2009), Aarikka-Stenroos et al. (2017, p. 89) define an extensive network as "a network setting which comprises a wide range of different actors and stakeholders (with regard to organizational logics, goals, discourses, and cultures, along with technologies and industry sectors)." It expands business network theory (focusing primarily on for profit business actors) (Håkansson et al., 2009) by augmenting it with the role of non-business actors (such as governmental agencies, different types of authorities, NGOs, trade unions or political parties). Thus, an extensive business network encompasses a variety of direct and indirect relationships among buyers and sellers and other nonbusiness actors. The (business) actors constitute dyadic business relationships as a straightforward interactive relationship between two parties (Håkansson, 1982). Moreover, they are affected by relationships with other (non-business) actors (Håkansson et al., 2009). Such non-business relationships may include, for example, ownership relationships, innovation collaborations, competitor relationships, or conflicts between actors Fncton and Araujo, 1992). Other non-business links includ $=f$ instance, the relationship between the regulatory authority and the regulated entities. However, we want to highlight the clear conceptual base rooted in the IMP approach as dyadic relationship evolve via triadic relationships (Simmel, 1910) into complex networks.

The ARA model (Håkansson and Snehota, 1995) grasps the ontological complexity of business networks to facilitate managerial feasibilit $=$ ctors, resources and activities are mutually related and innuence each other. Actor bonds refer to the way in which the parties involved in a business relationship perceive and identify each other. Resource ties refer to the way in which tangible and intangible resources supporting activities of two firms in a relationship become oriented towards and integrated with each other. Finally, activity links refer to the way in which the various activities undertaken by two firms in a relationship are coordinated and adapted to each other (Håkansson and Snehota, 1995). The existence of bonds between actors is a prerequisite for them to actively and consciously develop strong activity links and resource ties. Vice versa, activity links make it likely that bonds will develop (Håkansson and Snehota, 1995).

In the case of ports, we can identify a wide range of different business and non-business actors as the basis for the existence of a seaport (Notteboom and Winkelmans, 2002). The actors engage in local activities to create linkages with other (i.e. local, regional and global) actors. Furthermore, local, regional, and global actors involved in port activities are typically organizations. These organizations include both business and non-business actors such as companies and local, national or international regulatory bodies at different levels such as port authorities (PAs), national governments, trade unions, and various professional and/or civil organizations involving relationships and interactions of diverse nature on different levels (B2B, business-to-consumer [B2C], etc.) (Parola et al., 2018). 
Sustainable marketing in a B2B context

Alexandre Lavissiere, Tibor Mandják, Julian Hofmann and Laurent Fedi

Shipping companies and terminal operators are typical business actors whereas PAs or municipalities are typical nonbusiness actors. Aside from shipping companies as the most prevalent business actors related to ports, terminal operators, logistic operators, service operators such as tugboats, moorage companies or pilots and industries operating next to the terminals. Such port-related actors are worldwide organizations with interconnections in several ports. Some have connections in a certain type of ports in a specific region or culture, from a specific size or, from a specific trading route. Besides such operational activities, PAs take a pivotal position among the non-business actors in managing the whole regulatory

AQ: 1 framework (Fedi and Lavissière, 2014). The relationships between regulator and operators are typically non-business in nature. However, there are interactive business relationships among the different operators. On the highest level of aggregation, ports represent a multimodal interface between sea, road, rail and air modes of transports (Fedi, 2006). Such complexity of the relationships among port actors "holding heterogeneous resources, capabilities, and commitments" (Parola et al., 201 ji stifies the choice of the theory of business networks, the ARA model (Håkansson and Snehota, 1995), and the extensive network approach (Aarikka-Stenroos et al., 2017) to better understand the behavior of port actors in line with th $\mathrm{e}$ emerging port marketing strategies (Parola et al., 2018).

\subsection{Port marketing vs port community: What do we know so far?}

Academic literature on port marketing is in general scarce (Mandják et al., 2019). Mandják et al. (2019) conducted a systematic literature review of 369 scientific articles that as dealing with port- and marketing-related topics from the past 40 years. They identified most articles on port marketing being published in the port management domain in which marketing is mainly considered as a tool of competitiveness (Song and Panayides, 2008). Typical research questions concern the international competitiveness of seaports and the situation of global competition between ports (cf. Parola et al., 2017; Lagoudis et al., 2017). Contrary, only few articles have been published in core marketing journals (Mandják et al., 2019). Thus, port marketin $\xi=1$ at the intersection of different disciplines such as busmess marketing, maritime transport including both goods and persons - service management, logistics, maritime economics and supply chain management and has not yet been conceptualized as a comprehensive theoretical framework. Another evolving stream of research from port management deals with marketing management strategies that are merely contemplated from the PAs' perspective (Parola et al., 2018). However, within this second stream of research, researchers exhibit a growing interest in how marketing strategies can leverage established (port) management routines (Parola et al., 2018). Thus far, since the 1990s, researchers have been considering marketing as a strategic function - and sub-discipline - of seaport management (Branch, 1998; Cahoon, 2007; Cahoon and Notteboom, 2008; Figwer, 1999; Mester, 1991). The globalized context of the port industry in a situation of steeply increasing international competition (Brooks and Pallis, 2013; Cahoon, 2007; Pando et al., 2005) is pushing PAs to new missions and objectives (Olivier and Slack, 2006;
Journal of Business \& Industrial Marketing

Verhoeven, 2010). This transition has been facilitated by their new governance model inherited from the port devolution era in the 1990s that generalized the landlord port model (Brooks and Cullinane, 2007) redefining the perimeters of PAs actions towards more commercially oriented strategies such ns private companies. Nevertheless, it is noteworthy that PA $=\overline{\bar{a}}$ : mostly public entities (ESPO, 2016; World Bank, 2013) committed in regulatory functions (Comtois and Slack, 2003) especially safety, security an $l=\mathrm{e}$ vironmental protection (Cariou et al., 2014) and in commercial functions such as development and promotion of the port circumscription. Recent studies have illustrated the new role of PAs, highlighting entrepreneurial behavior and the emergence of marketing strategies (Parola et al., 2018; Van der Lugt et al., 2013).

However, two of the findings of the above-mentioned port marketing literature research seem to be particularly important. One is that authors assum

[...] that the business marketing approach is not the main approach to port marketing research. It is surprising not only because most of the actors in the field are organizations, but also because their business always takes place in a certain type of business relationships which, being strongly interrelated, form business networks (Mandják et al., 2019, p. 27).

The second finding which is strongly related to the first one is that there is a lack of the relational approach in the studied port marketing literature.

Leveraging marketing management of seaports from a B2B marketing angle while embracing interactive business networks leads us to the structural concept of "port community." In previous literature, this term is rarely mentioned and explicated (Dooms, 2019; Notteboom and Winkelmans, 2002). Among the few exceptions, most appearances in the literature are about a "Port Community Systems" (PCS) software that is globally used by numerous public and private actors of the port communit (IPCSA, 2016; Fedi et al., 2019. Furthermore, few scholars refer to a "port community" concept despite not providing any conceptualization beyond the PA's embeddedness and associated port management bodies (Dooms, 2019; Parola et al., 2018; Van der Lugt et al., 2013). To some extend the "port community" has been "negatively" perceived as an externality where conflicts occur (De Langen, 2006; Parola and Maugeri, 2013). Thus, the conceptualization of a holistically addressed "port community" represents a research gap in the existing literature.

\section{3 (Port) marketing embracing sustainability}

Sustainability is on the agenda of marketers and academics for about two to three decades. Literature mainly agrees on "that sustainable development encompasses environmental, economic, as well as social (equity) sustainability (Rogers et al., 2008)" (Mariadoss et al., 2011, p. 1306). Sticking to a classical "homo economicu 3 "- 1 erspective, sustainable marketing refers to keeping the output revel constant at an acceptable level while minimizing resources input (OECD, 2002). However, sustainability entering the political agenda is not self-evident as observed by the recent US termination of the Paris agreement (Zhang et al., 2017). The three pillars of sustainability (i.e. environmental, economic and social sustainability) are disentangled next.

Primarily, sustainability is associated with environmental sustainability. Marketing per se has been identified as one of the sources of unsustainable extensive environmental damage 
(Saha and Darnton, 2005) putting particular pressure on turning marketing to a more holistically value-chain embedded networkbased concept of sustainability. For marketers, serving custome1 need for (environmentally) sustainable products is operationalized on the level of the marketing mix - predominately focusing on B2C marketing (Jones et al., 2008). Facilitating corporate social responsibility (CSR) through green-labeled advertising campaigns, CSR initiatives incorporating partitioned pricing (such as in the case of voluntary $\mathrm{CO}_{2}$ expenses while booking airline trips) and/or using recycled spare parts and/or producing compostable or reusable products are among the most vivid examples. However, from a $\mathrm{B} 2 \mathrm{~B}$ perspective - which is outnumbering $\mathrm{B} 2 \mathrm{C}$ transactions - the sustainability concept is leveraged primarily through downstream value chain activities such as supply chain management. Existing literature highlights the gain of strategic competitive advantages though innovation based sustainable strategies. Environmentally conscious sustainable B2B "supply management would enable better waste management and inventory control through lean manufacturing, reuse, remanufacture and recycling, as well as a focus on product design for disassembly" (Sharma et al., 2010, p. 331). Reducin carbon emissions is among the most promising avenues for reducing environmental footprint through sustainable B2B supply chain management. Moreover, as B2B transactions embrace diverse buyer-seller relationships, the social component among the three "Es" (i.e. environmental, economic, as well as social [equity] sustainability) gets evident.

Among the logistics and transportation sector, port has a central importance because it constitutes a nodal point where means of transport converge (Rodrigue and Notteboom, 2009). Sustainability with regard to ports has primarily been assessed through negative externalities such as emissions and/or noise (Dooms, 2019). Whereas few international regulations are in force regarding the different sources of pollution from seaport facilities, national or regional regulatory frameworks are emerging, especially for reducing air pollution impacts for local population living near the shores. PAs are facing constraints to comply with new environmental legislations especially in the European Union (EU) (Cariou et al., 2014; Parola et al., 2017). Air pollution is considered as a major environmental risk to human health causing three million deaths per year (World Health Organization, 2016). However, green strategies have represented a major trend in port governance over recent years (ESPO, 2016). Green actions aiming to mitigate air pollution are progressively taken by ports. Ports are becoming "greener" with different levels of involvement in environmental compliance (Bergqvist and Monios, 2019; Lam and Notteboom, 2014) and play a new role in energy management (Acciaro et al., 2014; ESPO, 2016). However, these new greener ports (Bergqvist and Monios, 2019) implement specific measures generally focused on one main pollution source, in particular from ships, with the short-term objective of addressing one topical environmental concern such as ship's air pollution (Cullinane and Cullinane, 2019; Styhre and Winnes, 2019). Even though different types of pollution are addressed, few actors are involved, mainly shipping lines (Styhre et al., 2017) and the measures are mostly implemented through the PAs' initiatives (Fedi, 2013; Innes and Monios, 2018; Mellin and Rydhed, 2011), which face stricter mandatory rules notably in the E Juropean Parliament, 2014). Nonetheless, ports can have an influence on all three scales of sustainable development (SD), namely on the local, regional and global level. CSR and environmental aspects of ports have been set to light (Dinwoodie et al., 2012). Acciaro (2015) emphasizes the role of PAs to promote sustainable objectives under three major elements. At first, PAs as public bodies have to encourage and enforce regulation, including environmental and societal ones. Second, port development projects are now subjecting to impact studies in particular with regard to climate change adaptio $1=(\mathrm{Jg}$ et al., 2016), and incorporation of social and environinental aspects of development; and this applies to private projects as well. Third, ports as a central part of supply chains, enforce the whole supply chain to pursue sustainability objectives, as, consequently, port competitiveness depends also from social and environmental pillars.

Nevertheless, in the existing literature, sustainability is also contemplated at the scale of the PA to the same extend of port marketing and not at the port community level (yet). Overall, we observe that scholars have paid not much attention to a more holistic approach that would allow seaports to shift from "green ports" - that mainly implement greener measures at the environmental level - to "sustainable ports" which incorporate several pillars of sustainability. Thus, through our case method approach, we will elaborate on whether (and how?) the holistic concept of sustainability extends the more one-shot singular green-port labeled discussion prevalent in the existing literature. Thus, is a port community concept helping to evolve from green ports to sustainable ports?

In our view, the dominant approach of port marketing and associated green strategies in the existing literature have hindered the "positive" perception of the "port community." Then, rather than an externality where conflicts occur between stakeholders, authors assume that the relationships and interactions among actors in their port community can achieve successfully sustainable long-term projects and goals.

\section{Methodology}

Inductive research seems to be suitable for the generation and development of theories and concepts. It builds general patterns based on empirical observations (Patton, 2002). Accordingly, we applied a multiple case study research method for this paper. The case study method is particularly suited when exploring the density and complexity of recent phenomena (Yin, 2018) that cannot easily be broken down yet. As Eisenhardt (1989, p. 548) points out that "building theory from case study research is most appropriate in the early stages of research on a topic or to provide freshness in perspective to an already researched topic." It represents a common approach in industrial business research (Abbott, 1992; Dubois and Araujo, 2007; Easton, 1995). To build knowledge on new assumptions, case study research provides in depth, detailed and rich data. Moreover, the case study research enables a longitudinal approach that helps studying and modeling dynamics of business networks over time (Harrison and Kjellberg, 2010).

The selection of the cases studied was based on multiple criteria. First, we choose ports from different countries with different levels of development (Madagascar as a developing country, France as quite centralized OECD country, and the 


\subsubsection{Actors and activities in Ehoala Port}

USA as more decentralized federal state) and ports at different levels of their individual development. Second, we choose projects among these ports that were led by different focal actors (PAs, industries, logisticians). Third, we choose projects that were primarily centered on a different pillar of sustainable development. This is why we have three cases - one per pillar. This combination of different perspectives enables us to observe the evolution of the relationship between the port and the sustainable goals in a longitudinal way.

Collection of data followed the methodology developed by Yin (2018). Internal and external documentation on the projects were collected for the three cases. Concerning the cases in France and Madagascar, collection of data has initially been conducted for other projects (Fedi et al., 2019; Mandják and Lavissière, 2018) and were re-used as secondary data for these cases. Direct observation was made for the three cases. Participant observation was involved for the case of Le Havre in which two authors have been involved as experts and for the case of Madagascar for which one author was consultant to the mining company. These multiple sources, summarized in Table I, provided robust data that has been organized and presented from the perspective of an extensive network and project scope.

\section{Case studies}

In this chapter, following the logic of inductive research (Patton, 2002), we start by describing the three cases in detail and analyze them hereafter individually. Note that in each case, we focus on one project for each port. This is primarily because of analytical reasons. Namely, the analysis of a port project makes it easier to grasp the complexity of port activity. In addition, this simplification also provides the opportunity to show the changes over time.

\subsection{Port Ehoala's economic project in Madagascar}

Port Ehoala is a newly created port in the southern region of Anosy in Madagascar. It is a private port managed by a subsidiary of Rio Tinto, one of the world leading mining company. Rio Tinto acquired a concession to exploit ilmenite in three sites close to the city of Fort Dauphin. To refine this sand, Rio Tinto had to transport it in his plant in Canada, and therefore to build a deep see port facility.

QMM, the local subsidiary of Rio Tinto, which is partially owned by Malagasy State, needed to use the primary quay for about one week per month to export a total of 750,000 tons of ilmenite and 60,000 tons of zirsill each year. QMM also required the port to import equipment, machinery, materials, spare parts, and approximately 30,000 tons per year of fuel required to operate the mine.

The port was first meant to only serve as a link in the mining company activity cycle. However, when the facility master plan was developed, it was suggested by consultants to look for opportunities of optimization of the port as a resource to connect to other resources and by such develop new activities. No longer considered as a mono-client port, Ehoala project could target other types of flows. Cruise and containers were the two main new opportunities, as Ehoala would become by far, the deepest port of Madagascar.

This purely economic project, to be profitable, had to involve other actors. The ministry of tourism, the taxi companies, park authorities and local communities (markets, hotels, etc.) were considering cruise shipping. The local chamber of commerce, small local industries, shipping companies, international industries and institutions were considering development of container shipping.

Madagascar is one of the least developed countries in the world. Its infrastructure such as roads was cut part of the year because of heavy rair $=$ onsequently, a shipping line with a regular service was set to teed the island from the outside. After few years, Ehoala Port was used to export (other) goods, such as sisal and fishery products, and to import staple commodities (e.g. rice and flour) and construction materials (e.g. cement and steel). It also accommodates cruise tourism. 400 hectares of land are also dedicated for Ehoala Park, a free port area dedicated to warehousing and industrial facilities.

Because the project was including local development, World Bank granted funds to develop the port project. QMM, however, had to work with local communities to compensate the social and environmental impact of the industrial development in a natural ecosystem. The company worked closely with the International Union for Conservation of Nature and other NGOs with the aim to have a positive impact on the region.

\subsubsection{Analysis}

From an extensive network and ARA perspective, the case is showing three main phases of development with increasing

Table I Summary of the collection of data for the three cases

\begin{tabular}{|c|c|c|c|}
\hline Case study & Ehoala & San Pedro Bay & Le Havre \\
\hline Country & Madagascar & USA & France \\
\hline Port & Port Ehoala & $\begin{array}{l}\text { Port of Los Angeles } \\
\text { Port of Long Beach }\end{array}$ & Port of Le Havre \\
\hline Focal actor & Rio Tinto (Mining Company) & $\begin{array}{l}\text { Both PAs of } \\
\text { Los Angeles and Long Beach }\end{array}$ & Logistic operators of the port \\
\hline Primary pillar of SD & Economic & Environmental & Social \\
\hline Main collection of data & Participative observation & External documents & Interviews (23) \\
\hline Other collections of data & $\begin{array}{l}\text { External documents } \\
\text { Internal documents } \\
\text { Direct observations }\end{array}$ & Direct observations & $\begin{array}{l}\text { External documents } \\
\text { Internal documents } \\
\text { Direct observations } \\
\text { Participant observation }\end{array}$ \\
\hline
\end{tabular}


Figure 1 Extensive network of Port Ehoala economic project the mix of actors is including both private and public sector's actors.

In the first phase, there is mainly a financial relationship between the state and the mine to build a facility. This facility has firstly an economic purpose at the mine level because it enables the activation of the mine as a resource, thanks to the potential relationship the port brings to connect the mine with other plants that can refine the mineral. Second, the economic purpose for the state $\mathrm{i}$ a $\mathrm{b} b$ ut the creation of employment and GDP.

In the second phase, business relationships are created to develop new activities. The actors of the port start to involve both local and international actors to build the project of a port network that would contribute to everyone. This involves also moving from a purely economic perspective to a more social one with increasing concerns on local equitable development. Resources are shared and the network of actors enables more than one cycle of activity that is creating value.

Then in a third phase, the development of the activities goes toward a greener path making the project a sustainable project. Incorporating new actors and new activity cycles pushes toward an equitable development of the port and a viable and bearable port. Under the involvement of local communities, tourism is set up to enable the preservation of endemic species and the mining related activities are compensated by investments in surrounding areas.

This increase of actors in the network is evidencing the building of a port community around the project of Port Ehoala. In addition, the project with this growth is changing nature moving from a purely economic project to a wider project including progressively the two other pillars of sustainable development. What is interesting from a network perspective is also the reinforcing dynamic in which the constitution of the port community is driving the project toward sustainability and at the same time, the growing sustainability of the project is bringing new actors on board.

F1 Figure 1 is summarizing this phenomenon.

\subsection{The San Pedro Bay ports' ecological project in the USA}

In Southern California, the San Pedro Bay hosts next to each other two major ports. Created a century ago, the port of Los Angeles (POLA) and the port of Long Beach (POLB) constitute the leading entry point of cargo from Asia to the USA. Both are generalist ports handling different types of traffics. Since 2000, it has been ranked as the number one container port in the USA with around 9.5 million twenty equivalent units (TEUs) in 2018, followed by the POLB with more than 8 million TEUs. In terms of governance, the POLA and POLB are a department of the City of Los Angeles (LA) and Long Beach, respectively, and are managed by a board of harbor commissioners. Representing the San Pedro Bay ports complex, these two ports are in immediate vicinity to each other in which more than four million people live.

\subsubsection{Environmental issues}

Early in time, environmental protection and particularly air pollution have been considered as a serious concern in California. In 1991, the California Environmental Protection Agency (CalEPA) was established with the aim to enhance

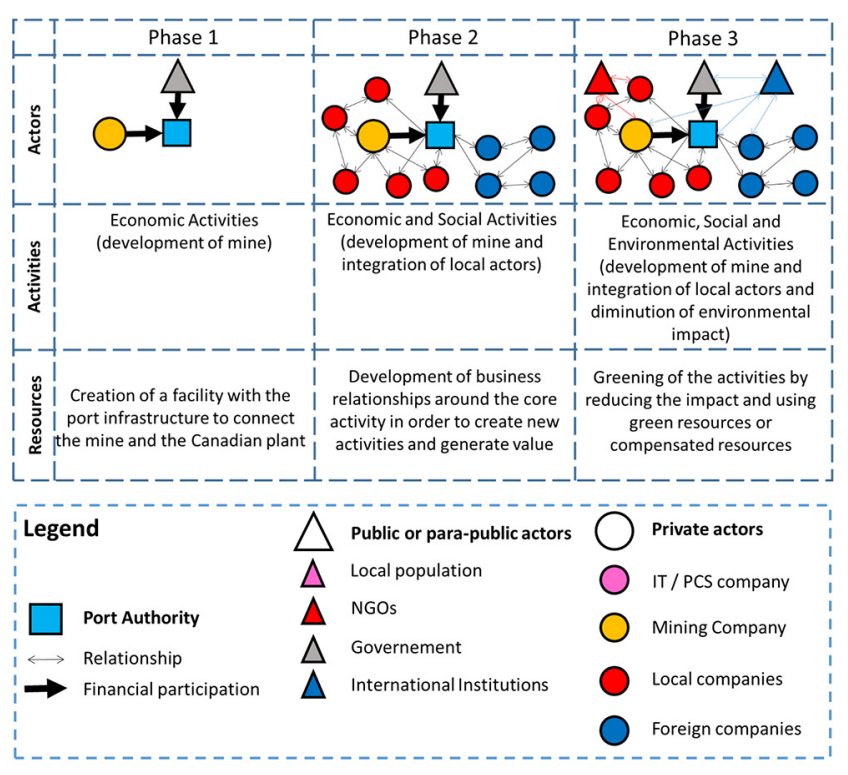

Source: The authors

environmental protection statewide and an ambitious policy was set up with the aim to improve air quality (CalEPA, 2019). The California Air Resource Board (CARB) was appointed to implement and monitor measures on air pollutants mitigation from industrial sources and motor vehicles (CARB, 2019). In 2006, the California Global Warming Solutions Act was voted requiring the state of California to reduce its $\mathrm{GHG}$ emissions to 1990 levels by 2020. Considering the growing development of POLA and POLB, notably in the container segment, a Clean Air Action Plan (CAAP) was also adopted for the San Pedro Bay ports complex in 2006. Updated twice in 2010 and 2017, the CAAP defined a comprehensive strategy for reducing portrelated air pollution emissions from cargo movement in and around the concerned ports associating private and public actors (CAAP, 2006). This project mainly involved truck companies, shipping lines, railroad operators, freight forwarders, terminal operators for private actors, the PAs, the environmental agencies (CalEPA, CARB) and completed by the South Coast Air Quality Management District (SCAQMD) for public actors.

The main air pollutants were targeted: Diesel Particulate Matter (DPM) that are microscopic particles from diesel exhaust and causing 60,000 premature deaths annually (Corbett et al., 2007), Nitrogen Oxides (NOx), that significantly contributes to smog and Sulfur Oxides (SOx), that endanger human health, generating acid deposition, and damaging water and soil qualities. Furthermore, the different means of transport were concerned such as ships, trains, trucks, and harbor crafts including terminal equipment. A slew of mandatory and voluntary measures were implemented through several programs. Regarding the mandatory ones, the 2008 Clean Trucks Program was launched with the aim to modernize port trucking industry and to reduce 80 per cent of air pollution induced by trucks before 2012 . A progressive ban schedule allowed elimination of the oldest and dirtiest trucks. 
To help financing the truck replacement or retrofit, a temporary fee of US $\$ 35$ per TEU was imposed. By 2010, more than 90 per cent of the fleet was renewed and by 2012, 100 per cent (CAAP, 2017). Since October 1, 2018, new trucks entering service at both ports need to be from the model year 2014 or newer. The same strategy was applied to terminal equipment with the will to replace older cargo-handling devices in a stepwise manner.

Furthermore, different measures have been taken to combat GHG from ocean-going vessels that call at the San Pedro Bay ports. New requirements entered into force on July 1, 2009, to both California internal waters/ports and all waters within $24 \mathrm{nmi}$ of the California baseline. As done in Europe with the Sulfur Emission Control Area (SECA), CA State decided to implement a SECA zone (IMO, 2010). The main engine, auxiliary boiler and auxiliary engines had to be operated with either marine gas oil (MGO) with a maximum of 1.5 per cent sulfur by weight or marine diesel oil (MDO) with a maximum of 0.5 per cent sulfur and 0.1 per cent since January 1, 2012 (Fedi, 2013). In addition, shore-side electricity (SSE) has been implemented in different port terminals with the purpose to reduce at-berth emissions from diesel auxiliary engines of vessels. These measures were completed by a voluntary speed reduction program. When ships slow down, fuel consumption and related emission indeed decrease (Cariou, 2011). The POLA and POLB proposed to ship operators this slow steaming from and to port facilities in compensation of a rebate on dockage rate.

\subsubsection{Analysis}

Since the adoption of the original CAAP in 2005, DPM emissions from mobile sources in and around the ports have decreased by 84 per cent, NOx by 50 per cent and SOx have nearly been eliminated (CAAP, 2017). The 2014 emission reduction and related health risk goals that were voluntarily set in 2010 were met and exceeded. Considering these positive outcomes, this environmental strategy indubitably appears as successful. One of the most valuable aspects of the CAAP is that the two ports have shared their resources, expertise and annually reviewed and updated their strategies with the port community taking into account progress and difficulties in the implementation strategies. In 2007, an Implementation Stakeholder Task Force was appointed with representatives from federal, state, air quality agencies, industry, environmental organizations, labor groups and academia to provide input for CAAP implementation plans. Moreover, the respective ports did a close monitoring, evaluation and reporting on performance of different actions in a transparent manner (Port of Los Angeles, 2019; Port of Long Beach, 2019).

F2-3 As shown in Figures 2 and 3, the significant amount of cooperation within the port community involving numerous actors, particularly the goods movement industry represented by terminal operators, shipping lines, maritime agents, freight forwarders, truck companies, regulatory agencies (CalEPA, CARB, SCAQMD), the multiagency coordinated approach and the port authorities of San Pedro Bay, is obviously one of the key success factors of the CAAP. Obviously, the positive outcomes in terms of air quality rest on the definition of shared goals with new stricter standards, co-funding (private and public), financial incentives from respective ports, and the codecision procedures conducted by the port community and the
Figure 2 Implementation of sustainable strategy with and through the port community

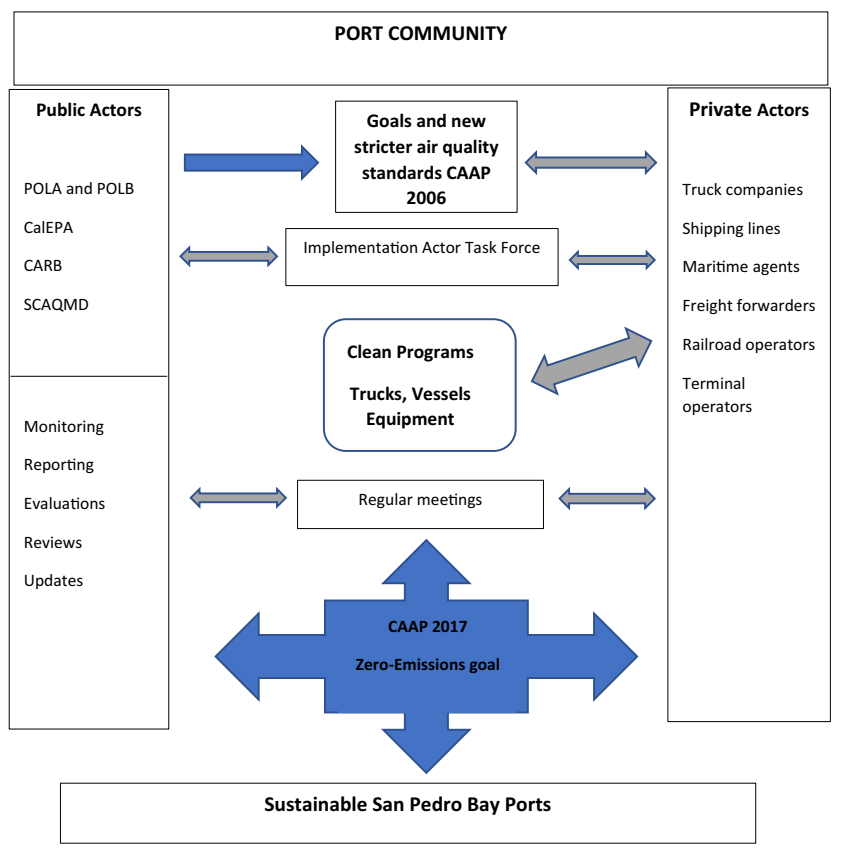

Source: The authors

Figure 3 Extensive network of the San Pedro Bay ports complex ecological project

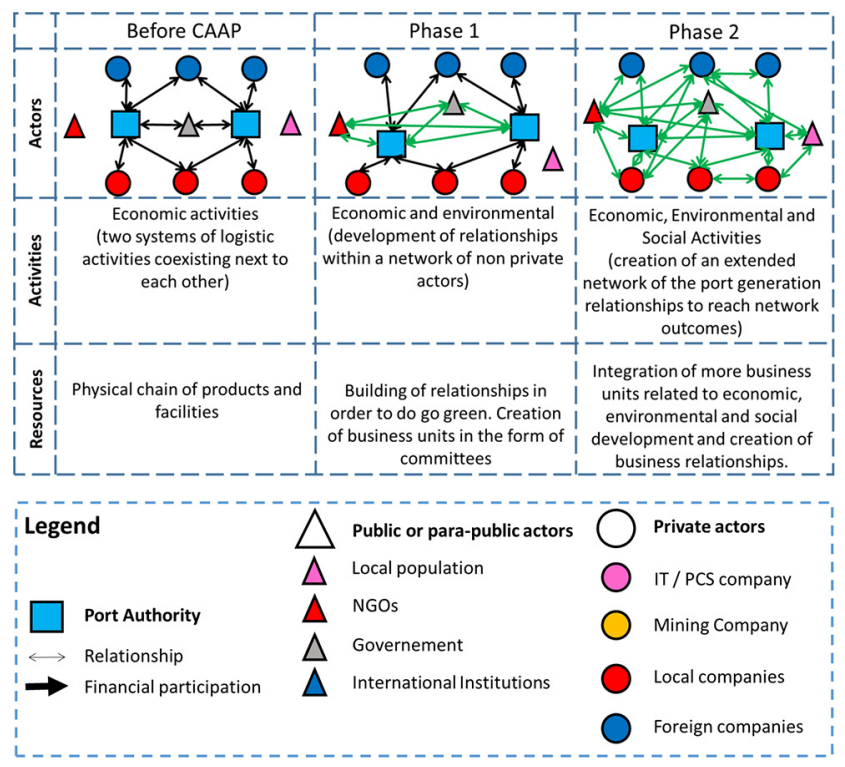

Source: The authors

public environmental bodies. The recent adoption of the 2017 CAAP clearly illustrated this community voluntary involvement and interaction. Two public workshops that drew 400 people and 50 meetings with more than 30 groups representing "thousand stakeholders" (CAAP, 2017) were held. The main driver of this approach was still to develop and 
implement sustainable strategies with and through the port community. Accordingly, following the different meetings on the new CAAP strategies, port stakeholders issued numerous comments notably on the timelines to transition to zeroemissions targets and the potential negative impacts on the San Pedro Bay ports complex's economic competitiveness. The managing boards of the $\operatorname{Pr} s=$ ok into consideration these observations and detailed answers and actions were proposed such as feasibility assessments or cost estimates. Finally, after two years of intensive dialogue and cooperation, the ports modified different elements of the initial strategies to reflect new evaluations and issued the draft final CAAP (2017) update.

The continuous commitment to improve air quality, working closely and cooperatively towards solutions to minimize adverse environmental impacts of operations, the long-term vision and port planning for the next 30 years (CAAP, 2017), have enabled the port community of San Pedro Bay to implement a sustainable development policy without detrimental effects on the economic and social side. Accordingly, they shift from a merely green ports model to sustainable ports with a "zero emissions" goal (CAAP, 2017). This strategy has allowed port development to continue, favoring job creation and economic activity. In 2018, the two ports handled around 17.5 million TEUs compared with 14 million in 2005. The San Pedro Bay complex creates one of nine jobs in the wider LA region representing 190,000 jobs for both ports, 992,000 jobs in California and three million jobs throughout the US (Port of Los Angeles, 2018, Facts and Figures). More than ever, these ports constitute major economic drivers at the local, regional, and national level.

\subsection{A social project in the port of Le Havre (France)}

In February 2007, three rows of a stack of containers collapsed on board of the MV Limari within the port of Damietta (Egypt). The load was exceeding by more than 300 per cent the declared weight. In February 2011 in Darwin port (Australia), a container fell $12 \mathrm{~m}$. The declared weight was 4 tons, when the real one was 28 tons. Two workers had to run to avoid the falling containers. In June 2011, during an unloading process in Algeciras (Spain), the container ship Deneb was destabilized forcing the crew to escape the ship. The ship's instability was caused by 16 overloaded containers (out of a total of 168 containers) whose weight was four times higher than the declared one. Fuel and oils were shipped on that vessel. This incident generated major polluting risks (Lebourg et al., 2016)

International Maritime Organization (IMO) is the Unitea Nations Agency for maritime issues, especially security, safety, and environment. In 1974, the Safety of Life at Sea (SOLAS) Convention has been signed by 162 contracting states, representing around 99 per cent of the world's merchant fleet. The Chapters VI Regulations 1 and 2 of SOLAS set out the procedure and responsibility to declare the weight of containers. However, the accidents occurring in the container industry because of misdeclarations forced IMO members to adopt a dedicated regulation on verified gross mass (VGM) that enters into force July 1, 2016 (Lavissière et al., 2017).

Since then, in every port of every country, a container should not be loaded when the shipper did not provide the VGM of the container. This new regulation was at least imposing a new task to perform within supply chains that are in general very tense.

\subsubsection{Port of Le Havre}

We studied what happened in the Port of Le Havre before and after the VGM implementation date. Before the implementation, actors of the port of Le Havre reacted to the new regulation by considering adequate response strategies. The PA and the union of private actors of the port (Union Maritime et Portuaire UMEP) started lobbying with the French government to influence the decree of application. At the same time, terminal operators were also involved in steering committees with the government. They were able to present their position and tried to influence the future decree to facilitate their handling activities while providing the required safety. Other actors in Le Havre also started to get ready their own way. The Port Community System (PCS) company started to develop an add-on dedicated to VGM. A company that possessed the only weighing balance for trucks in the port area started to develop an offer to weigh the containers in the port. Local freight forwarders invested in trainings to be ready to be certified for calculation methods.

After the implementation date, there were six months of tolerance. During this period, terminal operators and freight forwarders observed how the implementation worked. Meanwhile, the PCS company started to request feedbacks from the actors of the chain on the VGM add-on (Fedi et al., 2019). This made the companies work together to have both a safe (as required by law) and efficient system. Once the PCS was ready to function in interface with all actors of the chain in a manner that would make the supply chain fluid, terminal operators, logisticians and freight forwarders started to work together to provide efficient and systematic systems of providing VGM. In the following year, French ports, and especially Le Havre, have been pointed out as ports in which the VGM implementation was a success.

\subsubsection{Analysis}

In the case of implementation of VGM, there is a clear will to develop the social pillar of sustainable development that safety constitutes a major element. What is interesting here is that this safety issue is imposed by a supra-governmental organization (IMO). Then, in the first phase, involved actors are trying to influence the application of this regulation locally. At this stage, it is of individual interest driven by economic concerns. The VGM regulation imposes a new task to perform in the supply chain and this task requires communication of information with several actors of the chain that are not directly linked. For instance, the shipper has to provide the VGM to the ship owner, but the latter delegates the loading to the terminal operator and the shipper often delegates the weighing to the transporter or the freight forwarder. This creates a complex situation.

As illustrated in Figure 4, this first phase is therefore a phase of opportunistic tactics in which actors are trying to push for their own economic interests. We notice however, there are also actors who represent other actors, such as the UMEP, and these actors are trying to push for the interest of a group of actors.

In the second phase, the actors start to work together and consolidate their relationships around the need for an efficient regulation implementation. The implementation is too complex to be a simple optimization of the linear supply chain. It requires physical and informational management of flows. 
Sustainable marketing in a B2B context

Alexandre Lavissiere, Tibor Mandják, fulian Hofmann and Laurent Fedi

Figure 4 Extensive network of VGM implementation

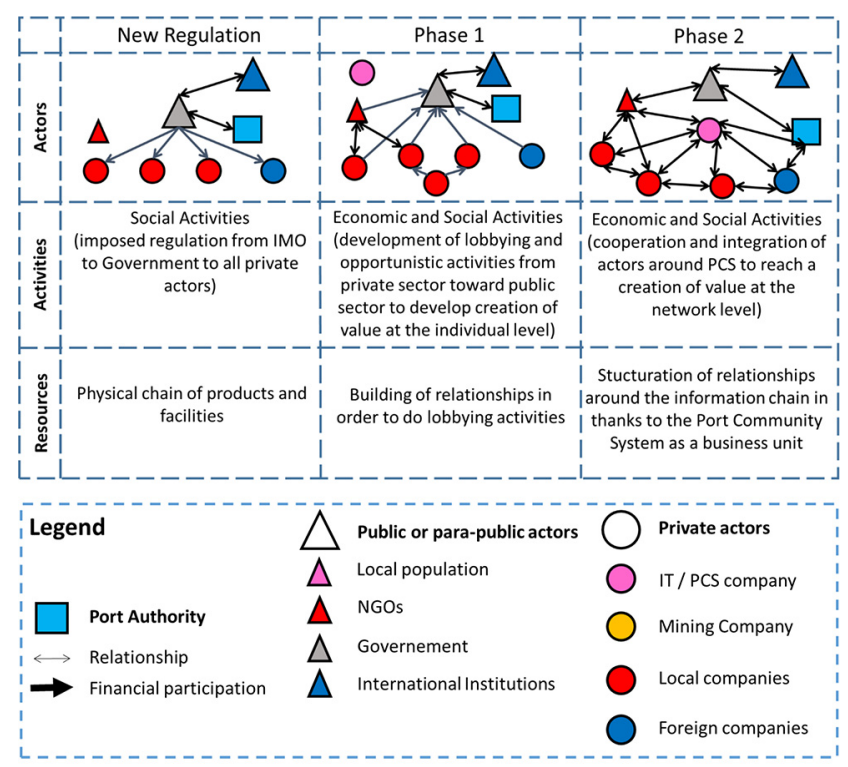

Source: The authors

Around the information flow, the actors will start to build a network strategy, for the good of the system rather than only the individual actors. The PCS in that case is a representation of this network that is sharing knowledge to build an information system that binds them together.

Actors are, in this process, consolidating a port community that is interestingly represented by the PCS. This network, or port community, is not only the PA, or the internal actors of the port, but a wider community of actors that are not necessarily based in the port (headquarters, subsidiaries or agents), directly related to the container handling (logisticians) or physical flows-driven. The port community is therefore a much wider concept than the port supply chain.

\section{Discussion}

Following the logic of inductive research (Patton, 2002), the final step is to identify general patterns based on the detailed description of the cases. These patterns help us to answer our two research questions initially raised and consequently to highlight the positive structural role of the port community

\subsection{The relationship between port community and sustainability}

Based on ports being extensive business networks, we conceptualize a port community as follows: a port community is an extensive business network interpreted at a geographically specified point encompassing a multitude of economic and non-economic actors, evolved relationships between them and physical and organizational resources involved. The basic social performance or output of a port community as an extensive network is to ensure the interconnection of maritime and land activities. In addition, in an extensive network, the behavior of the actors cannot be separated from the network. However, the actors still have some degrees of freedom in their managerial decisions. Hence, it is important to point out that this (social)
Journal of Business \& Industrial Marketing

goal only means that it is the performance of the port network as a whole, but which does not mean that the individual members of the port community do not primarily follow their own goals. The port community is not merely an externality including different components such as civil society, territory and environment where conflicts occur (Notteboom and Winkelmans, 2002; Parola and Maugeri, 2013). The port community is a network structure and it merely expresses that the members of the port community coexist and depend on each other in different depth. Of course, this does not exclude the possibility of conscious and organized cooperation, as we have seen in the case of the San Pedro Bay ports.

We have discussed different examples of the evolution of ports towards a more sustainable development which is in fact beyond isolated actions of individual[1] actors such as PAs in the case of San Pedro Bay ports, PAs and unions (UMEP) in the case of Le Havre or as the mining company in the case of Ehoala Port. Actors of the port network have strong dyadic as well as triadic relationships leading towards an extensive network. Moreover, we identified a temporal pattern. The involvement of different actors in the port environment is increasing from a single actor to the whole network of involved actors.

The scope of activities evolves from a single pillar to all three pillars of sustainability. Port projects striving towards sustainability (might) encompass several pillars of development. Some projects are confined on one pillar of sustainable development (either economic [e.g. Ehoala port Phase 1], environmental or social). Whereas some projects, or sometimes the evolution of some projects are covering two pillars of sustainable development and make it viable (environmental and economic), equitable (economic and social [e.g. Ehoala port - Phase 2]) or bearable (social and environmental) projects. Even few projects are also taking into consideration all three pillars to become holistically sustainable [e.g. Ehoala port - Phase 3]. We notice that it is a mutually reinforcing dynamic between actors and activities. Moreover, there is neither a sustainable project that is only happening within the scope of a single actor, nor a network driven project that is only focused on a single pillar of sustainability.

Further, the dynamic across phases also reveals the importance of the resources involved. Many isolated latent resources involved become activated along the course of the described dynamic and get connected and integrated into a network alongside complexity.

Figure 5 conceptualizes the dynamic mutual relationship between port community (structured according to the ARA model) and the three pillars of sustainability. Moreover, as described above, it tries to visualize how the three ARA elements, activities, actors, and resources, move from their initial level (as an example - economic, environmental or social activities) to their highest level (as an example - overall sustainable activities) as shown through the different phases of our case studies. Hence, the reinforcing aspects of the three elements of the ARA model (exemplified through ports) provide managers and scholars alike with a powerful tool to study sustainable networks in the future.

However, the above representation not only draws attention to the interdependence of the port community and the sustainability pillars through their activities and relationships. Indeed, the port community's extensive network approach also 
Sustainable marketing in a B2B context

Alexandre Lavissiere, Tibor Mandják, fulian Hofmann and Laurent Fedi

Figure $\mathbf{5}$ The different relations between port community and sustainability

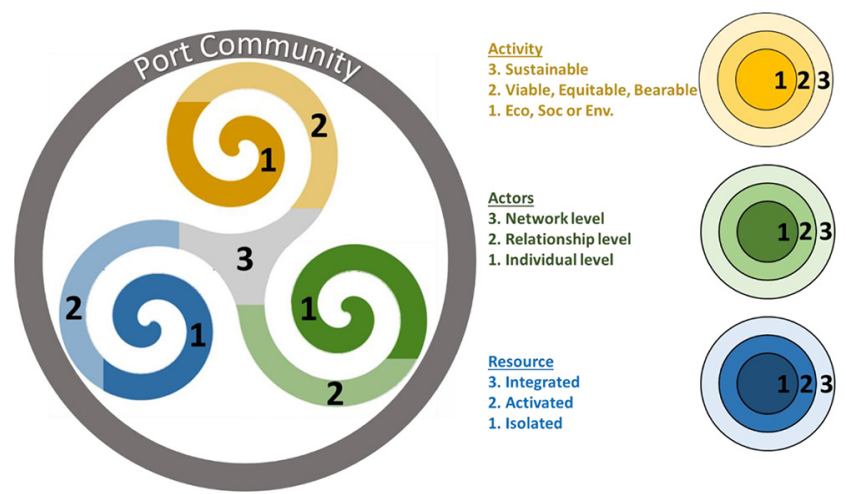

Source: The authors

points out that if any component of the network changes, this change will, to some extent, also affect other actors of the network. In this context, the port community is an interface between community members and sustainability pillars. One consequence of this is that any change in sustainability pillars has a direct or indirect impact on all members of the network, i.e. the port community. The other, theoretically important consequence is that the realization of any of the three pillars is possible only through and by the network.

As port sustainability has been interpreted as the co-existence of the three sustainability pillars, we can assert that port sustainability can only be achieved through the port community and, thus, through the activities of the port community. In the network (i.e. in the port community), actors interpret and make sense of the network according to their individual, collective or social interests. These interpretations form the basis of the actors' networking activities and their decisions. In the network, this concerns the decision to maintain or change the status quo (Medlin and Törnroos, 2014).

However, in the network, one actor, alone, is unable to make changes, which requires assembly of actors and joint aspiration of a group of actors (Aarikka-Stenroos et al., 2017):

Everything is possible if an actor gets the support of the network, while at the same time nothing can be done if the network goes against the actor. Therefore, bonds to others affect the possibilities for action (Håkansson and Snehota, 1995, p. 201).

\subsection{Port community and the process of becoming a sustainable port from a green port}

In the dominant approach of port marketing and associated green strategies, it is generally observed that green ports implement spot measure(s) in short or medium term to address environmental urgencies (Bergqvist and Monios, 2019). Moreover, actions are targeted on one aspect of sustainability (mainly the environmental pillar), are largely focused on one pollution source (ship's air emission for instance) and involve only few actors.

All three cases show that changes are happening through and by the port community. However, these changes demand the gathering and the joint aspiration of different actors. This joint aspiration may emerge from the actors' economic interest as in
Journal of Business \& Industrial Marketing

the case of Ehoala Port or may come from the local government and PAs as in the case of the San Pedro Bay ports while at international level as in the case of VGM in Le Havre.

More precisely, the example of the San Pedro Bay ports shows that a significant amount of cooperation within the port community enabled the shift from a merely green port to a sustainable port. Owing to the strong success of the CAAP (2017) in San Pedro Bay ports, successfully implemented port communities leverage moving from green ports to sustainable ports.

Thus, based on our case integration we conceptualize a sustainable port as a port that implements long term-oriented different measures encompassing different pollution sources in a systemic way (inland and seaside for instance), acting on all three pillars of sustainability and involving a wide range of interlinked actors at the port community level.

\section{Conclusion}

Our research contributes to the business and industrial marketing literature in general and especially to the yet hitherto scarce port marketing literature in more particular in the following ways. In our conceptual paper, we have been the first (to the best of our knowledge) to define port community as an extensive business network interpreted at a geographically specified point encompassing a multitude of economic and non-economic actors, evolved relationships between them and physical and organizational resources involved. Moreover, we pointed out the mutual interaction between port community and sustainability pillars. The port community is a structural interface between individual members of the port community and sustainability. Hence, port sustainability can be achieved through and by the port community. Finally, we exemplify how green ports can overcome relying on spot measure(s) to evolve toward more holistic sustainable ports. Thus, we conceptualize a sustainable port as a port that implements long term-oriented different measures encompassing different pollution sources in a systemic way (inland and seaside for instance), acting on all three pillars of sustainability and involving a wide range of interlinked actors at the port community level.

According to our conceptualization of a port community, we are able to emphasize its positive structural role in facilitating meaningful engagement of all business and non-business actors for sustainable projects. Considering the managerial implications of this research, a port community can be interpreted as a strategic and valuable asset within and outside the port environment. For business or non-business actors, either for PAs or for policymakers, the most important message is that acting independently from each other could not guarantee success. The emerging "smart port" initiatives express the strategic role of all actors together who pool their resources to achieve sustainable port development. Moreover, our emphasis on port community is also meeting recently observed new forms of cooperation at a national and international level. It involves strong interactions of different port communities to carry out shared marketing projects to strengthen their collective competitiveness.

Owing to its conceptual nature based on empiricalqualitative research, our research evidences some limitations, which opens avenues for further research. First, more 
elaborated analyses on the three pillars of sustainability provide promising deepening potential. Second, although we tried to provide a diverse illustration when selecting the cases, future research should examine if and to what extant our findings can be replicated considering that the existence of the port community does not guarantee a successful cooperation organized for a common purpose. This would allow more finegrained theoretical implications in general but also more customized managerial advice as different port types (Flynn et al., 2011) have different port communities in terms of composition and actors' behavior.

To conclude, this paper highlights that ports represent a powerful context of research within business and industrial marketing at the interface to sustainable marketing. In contemplating port marketing in a $\mathrm{B} 2 \mathrm{~B}$ context, we pointed out a new research perspective beyond the port authority-centric approach that scholars have prioritized so far (Parola et al., 2018).

\section{Note}

1 Emphases in italics refer to Figure 5.

\section{References}

Aarikka-Stenroos, L. and Ritala, P. (2017), "Network management in the era of ecosystems: systematic review and management framework", Industrial Marketing Management, Vol. 67 No. 4, pp. 23-36.

Aarikka-Stenroos, L., Sandberg, B. and Lehtimäki, T. (2014), "Networks for the commercialization of innovations: a review of how divergent network actors contribute", Industrial Marketing Management, Vol. 43 No. 3, pp. 365-381.

Aarikka-Stenroos, L., Jaakkola, E., Harrison, D. and MäkitaloKeinonen, T. (2017), "How to manage innovation processes in extensive networks: a longitudinal study", Industrial Marketing Management, Vol. 67 No. 4, pp. 88-105.

Abbott, A. (1992), "What do cases do? Some notes on activity in sociological analysis", in Ragin, C.C. and Becker, H.S. (Eds), What Is a Case? Exploring the Foundations of Social Inquiry, Cambridge University Press, Cambridge, MA, pp. 53-82.

Acciaro, M. (2015), "Corporate responsibility and value creation in the port sector", International Fournal of Logistics Research and Applications, Vol. 18 No. 3, pp. 291-311.

Acciaro, M., Ghiara, H. and Inés Cusano, M. (2014), "Energy management in seaports: a new role for port authorities", Energy Policy, Vol. 71 No. 3, pp. 4-12.

Aguinis, H. and Glavas, A. (2012), "What we know and don't know about corporate social responsibility: a review and research agenda", fournal of Management, Vol. 38 No. 4, pp. 932-968.

Bergqvist, R. and Monios, J. (2019), "Green ports in theory and practice”, in Bergqvist, R. and Monios, J. (Eds), Green Ports: Inland and Seaside Sustainable Transportation Strategies, Elsevier, Cambridge, MA, pp. 1-17.

Branch, A.E. (1998), Maritime Economics: Management and Marketing, 3rd ed., Stanley Thornes, Cheltenham.
Brooks, M.R. and Cullinane, K. (2007), "Introduction", Research in Transportation Economics, Vol. 17 No. 1, pp. 3-28.

Brooks, M.R. and Pallis, A.A. (2013), "Editorial: advances in port performance and strategy", Research in Transportation Business E Management, Vol. 8 No. 1, pp. 1-6.

CalEPA (2019), “California environmental protection agency web site", available at: https://calepa.ca.gov/

CARB (2019), "California air resources board web site", available at: https:/ww2.arb.ca.gov/

Cahoon, S. (2007), "Marketing communications for seaports: a matter of survival and growth", Maritime Policy $\mathcal{E}$ Management, Vol. 32 No. 2, pp. 151-168.

Cahoon, S. and Notteboom, T. (2008), "Port marketing tools in a logistics-restructured market environment: the quest for port loyalty", Proceedings of the International Association of Maritime Economists Annual Conference, Dalian, 2-4 April.

CAAP (2006), "San Pedro Bay ports clean air action plan 2006 technical report”, June 2006, p. 29, available at: www.polb. com/civica/filebank/blobdload.asp?BlobID $=2963$

CAAP (2017), "San Pedro Bay ports clean air action plan 2017 draft final clean air action plan update", July 2017, p. 73, available at: www.portoflosangeles.org/pola/pdf/caap_2017_ draft_document-final.pdf

Carbone, V., Moatti, V. and Vinzi, V.E. (2012), "Mapping corporate responsibility and sustainable supply chains: an exploratory perspective", Business Strategy and the Environment, Vol. 21 No. 7, pp. 475-494.

Cariou, P. (2011), "Is slow steaming a sustainable means of reducing $\mathrm{CO}_{2}$ emissions from container shipping?", Transportation Research Part D: Transport and Environment, Vol. 16 No. 3, pp. 260-264.

Cariou, P., Fedi, L. and Dagnet, F. (2014), "The new governance structure of French seaports: an initial postevaluation", Maritime Policy E Management, Vol. 41 No. 5, pp. 430-443.

Chen, J., Zheng, T., Garg, A., Xu, L., Li, S. and Fei, Y. (2019), "Alternative Maritime power application as a green port strategy: barriers in China", fournal of Cleaner Production, Vol. 213 No. 1, pp. 825-837.

Comtois, C. and Slack, B. (2003), "Innover l'autorité portuaire au $21^{\text {ème }}$ siècle: un nouvel agenda de gouvernance", Les Cahiers Scientifiques du Transport, Vol. 44, pp. 11-24.

Corbett, J.J., Winebrake, J.J., Green, E.H., Kasibhata, P., Eyring, V. and Lauer, A. (2007), "Mortality from ship emissions: a global assessment”, Environmental Science \& Technology, Vol. 41 No. 24, pp. 8512-8518.

Cullinane, K. and Cullinane, S. (2019), "Policy on reducing shipping emissions: implications for 'green ports", in Bergqvist, R. and Monios, J. (Eds), Green Ports: Inland and Seaside Sustainable Transportation Strategies, Elsevier, Cambridge, MA, pp. 35-62.

Daly, H.E. and Cobb, J.B. Jr (1999), "For the common good", fournal of Business Administration and Policy Analysis, Vols 27/29, pp. 65-86.

De Langen, P.W. (2006), "Stakeholders, conflicting interests and governance in port clusters", Research in Transportation Economics, Vol. 17, pp. 457-477.

Dinwoodie, J., Tuck, S., Knowles, H., Benhin, J. and Sansom, M. (2012), "Sustainable development of Maritime 
operations in ports", Business Strategy and the Environment, Vol. 21 No. 2, pp. 111-126.

Dooms, M. (2019), "Stakeholder management for port sustainability: moving from ad-hoc to structural approaches", in Bergqvist, R. and Monios, J. (Eds), Green Ports: Inland and Seaside Sustainable Transportation Strategies, Elsevier, Cambridge, MA, pp. 63-84.

Dubois, A. and Araujo, L. (2007), "Case research in purchasing and supply management: opportunities and challenges", fournal of Purchasing and Supply Management, Vol. 13 No. 3, pp. 170-181.

Easton, G. (1995), "Methodology and industrial networks", in Möller, K. and Wilson, D.T. (Eds), Business Marketing: An Interaction and Network Perspective, Kluver, Boston, MA, pp. 411-492.

Easton, G. and Araujo, L. (1992), "Non-economic exchange in industrial networks", in Axelsson, B. and Easton, G. (Eds), Industrial Networks: A New View of Reality, Routledge, London and New York, NY, pp. 62-87.

Eisenhardt, K.M. (1989), "Building theories from case study research", Academy of Management Review, Vol. 14 No. 4, pp. 532-550.

ESPO (2016), Trends in EU Ports Governance 2016, ESPO, Brussels.

European Parliament (2014), "Directive 2014/94/EU of the European parliament and of the council of 22 October 2014 on the deployment of alternative fuels infrastructure", Official Journal L 307/1 of October 28, 2014.

Fedi, L. (2006), "Le cadre juridique de l'exploitation des terminaux pétroliers [in French]", Doctoral Dissertation, University Aix-Marseille 3.

Fedi, L. (2013), “Air pollution from ships: towards harmonization or atomization of rules? A plea in favor of a feasible and universal regime for shipping industry", Proceedings of the Annual Conference of the International Association of Maritime Economist, IAME Conference, Marseille, 3-5 July.

Fedi, L., Lavissière, A., Russell, D. and Swanson, D. (2019), "The facilitating role of IT systems for legal compliance: the case of port community systems and container verified gross mass (VGM)", Supply Chain Forum: An International fournal, Vol. 20 No. 1, pp. 29-42.

Figwer, H. (1999), "Marketing orientation in polish seaports", in Roe, M. (Ed.), Strategic Management in the Maritime Sector: A Case Study of Poland and Germany, Ashgate Publishing Aldershot, pp. 16-28.

Flynn, M., Lee, P.T.W. and Notteboom, T. (2011), "The next step on the port generations ladder: customer-centric and community ports", in Notteboom, T. (Ed.), Shipping, Ports and Logistics, Academic and Scientific Publishers Brussels, pp. 497-510.

Håkansson, H. (1982), International Marketing and Purchasing of Industrial Goods: An Interaction Approach, John Wiley \& Sons Chichester.

Håkansson, H. and Snehota, I. (1995), Developing Relationships in Business Networks, Routledge London.

Håkansson, H., Ford, D., Gadde, L.-E., Snehota, I. and Waluszewski, A. (2009), Business in Networks, John Wiley \& Sons Chichester.
Harrison, D. and Kjellberg, H. (2010), "Segmenting a market in the making: industrial market segmentation as construction", Industrial Marketing Management, Vol. 39 No. 5, pp. 784-792.

IMO (2010), "Resolution MEPC.190(60) Amendments to the annex of the protocol of 1997 to amend the international convention for the prevention of pollution from ships, 1973, as modified by the protocol of 1978 relating thereto - North American emission control area", 26 March 2010, London.

Innes, A. and Monios, J. (2018), "Identifying the unique challenges of installing cold ironing at small and medium ports - the case of Aberdeen", Transportation Research Part D: Transport and Environment, Vol. 62, pp. 298-313.

IPCSA (2016), Port Community Systems Role in Enhancing the Efficiency of European Ports, IPCSA, Felixstowe.

Jones, P., Clarke-Hill, C., Comfort, D. and Hillier, D. (2008), "Marketing and sustainability", Marketing Intelligence $\mathcal{E}$ Planning, Vol. 26 No. 2, pp. 123-130.

Lagoudis, I.N., Theotokas, I. and Broumas, D. (2017), "A literature review of port competition research", International Journal of Shipping and Transport Logistics, Vol. 9 No. 6, pp. 724-762.

Lam, J.S.L. and Notteboom, T. (2014), "The greening of ports: a comparison of port management tools used by leading ports in Asia and Europe", Transport Reviews, Vol. 34 No. 2, pp. 169-189.

Lavissière, A., Fedi, L. and Russell, D. (2017), "Verified gross mass (VGM) adoption at leading seaports: a diffusion of innovation assessment of implementation", Proceedings of the International Association of Maritime Economists Annual Conference, Kyoto, 27-30 June.

Mandják, T., Lavissière, A., Hofmann, J., Bouchery, Y., Lavissère, M.C., Faury, O. and Sohier, R. (2019), "Port marketing from a multidisciplinary perspective: a systematic literature review and lexicometric analysis", Transport Policy, forthcoming.

Mariadoss, B.J., Tansuhaj, P.S. and Mouri, N. (2011), "Marketing capabilities and innovation-based strategies for environmental sustainability: an exploratory investigation of B2B firms", Industrial Marketing Management, Vol. 40 No. 8, pp. 1305-1318.

Medlin, C.J. and Törnroos, J.-Å. (2014), "Interest, sensemaking and adaptive processes in emerging business networks - an Australian biofuel case”, Industrial Marketing Management, Vol. 43 No. 6, pp. 1096-1107.

Mellin, A. and Rydhed, H. (2011), “Swedish ports' attitudes towards regulations of the shipping sector's emissions of $\mathrm{CO}_{2}$ ", Maritime Policy \& Management, Vol. 38 No. 4, pp. 437-450.

Mester, B. (1991), "Marketing from the port's point of view", Port Management Textbook, Vol. 3, pp. 33-58.

Ng, A.K.Y., Becker, A., Cahoon, S., Chen, S.L., Earl, P. and Yang, Z. (2016), Climate Change and Adaptation Planning for Ports, Routledge Abingdon.

Notteboom, T. and Winkelmans, W. (2002), "Stakeholders relations management in ports: dealing with the interplay of forces among stakeholders in a changing competitive environment", Proceedings of the International Association of Maritime Economists Annual Conference, Panama City, Panama. 
OECD (2002), Towards Sustainable Household Consumption? Trends and Policies in OECD Countries, OECD Paris.

Olivier, D. and Slack, B. (2006), "Rethinking the port", Environment and Planning A: Economy and Space, Vol. 38 No. 8, pp. 1409-1427.

Pando, J., Araujo, A. and Maqueda, F.J. (2005), "Marketing management at the world's major ports", Maritime Policy $\mathcal{E}$ Management, Vol. 32 No. 2, pp. 67-87.

Parola, F. and Maugeri, S. (2013), "Origin and taxonomy of conflicts in seaports: towards a research agenda", Research in Transportation Business E Management, Vol. 8, pp. 114-122.

Parola, F., Ferrari, C., Tei, A., Satta, G. and Musso, E. (2017), "Dealing with multi-scalar embeddedness and institutional divergence: evidence from the renovation of Italian port governance", Research in Transportation Business $\mathcal{E}$ Management, Vol. 22, pp. 89-99.

Parola, F., Pallis, A.A., Risitano, M. and Ferretti, M. (2018), "Marketing strategies of port authorities: a multidimensional theorization", Transportation Research Part A: Policy and Practice, Vol. 111, pp. 199-212.

Patton, M.Q. (2002), Qualitative Research E Evaluation Methods, 3rd ed., Sage Publications Thousand Oaks, CA.

Peloza, J. and Shang, J. (2011), "How can corporate social responsibility activities create value for stakeholders? A systematic review", fournal of the Academy of Marketing Science, Vol. 39 No. 1, pp. 117-135.

Port of Los Angeles (2019), "Port of Los Angeles web site", available at: www.portoflosangeles.org/

Port of Los Angeles (2018), "Facts and figures 2018", p. 2.

Port of Long Beach (2019), "Port of Long Beach web site", available at: www.polb.com/about/default.asp

Rodrigue, J.P. and Notteboom, T. (2009), "The terminalization of supply chains: reassessing the role of terminals in port/hinterland logistical relationships", Maritime Policy E Management, Vol. 36 No. 2, pp. 165-183.

Rogers, P.P., Jalal, K.F. and Boyd, J.A. (2008), "An introduction to sustainable development”, in Soederbaum, P. (Ed.), Understanding Sustainability Economics, Earthscan London.

Saha, M. and Darnton, G. (2005), "Green companies or green con-panies: are companies really green, or are they pretending to be?", Business and Society Review, Vol. 110 No. 2, pp. 117-157.

Sharma, A., Iyer, G.R., Mehrotra, A. and Krishnan, R. (2010), "Sustainability and business-to-business marketing: a framework and implications", Industrial Marketing Management, Vol. 39 No. 2, pp. 330-341.

Shi, W. and Li, K.X. (2017), "Themes and tools of maritime transport research during 2000-2014", Maritime Policy $\mathcal{E}$ Management, Vol. 44, pp. 151-169.

Simmel, G. (1910), "How is society possible?", American fournal of Sociology, Vol. 16 No. 3, pp. 372-391.

Song, D.W. and Panayides, P.M. (2008), "Global supply chain and port/terminal: integration and competitiveness", Maritime Policy \& Management, Vol. 35 No. 1, pp. 73-87.

Styhre, L. and Winnes, H. (2019), "Emissions from ships in ports”, in Bergqvist, R. and Monios, J. (Eds), Green Ports:
Inland and Seaside Sustainable Transportation Strategies, Elsevier Cambridge, MA, pp. 35-62.

Styhre, L., Winnes, H., Black, J., Lee, J. and Le-Griffin, H. (2017), "Greenhouse gas emissions from ships in ports - case studies in four continents", Transportation Research Part D: Transport and Environment, Vol. 54, pp. 212-224.

Tseng, P.H. and Pilcher, N. (2019), "Evaluating the key factors of green port policies in Taiwan through quantitative and qualitative approaches", Transport Policy, Forthcoming.

Van der Lugt, L., Dooms, M. and Parola, F. (2013), "Strategy making by hybrid organizations: the case of the port authority", Research in Transportation Business \& Management, Vol. 8, pp. 103-113.

Verhoeven, P. (2010), "A review of port authority functions: towards a renaissance?”, Maritime Policy \& Management, Vol. 37 No. 3, pp. 247-270.

World Bank (2013), "World bank port reform toolkit", June 2019, available at: www.ppiaf.org/sites/ppiaf.org/files/ documents/toolkits/Portoolkit/Toolkit/index.html

Yin, R.K. (2018), Case Study Research and Applications. Design and Methods, 6th ed., Sage Publications Thousand Oaks, CA.

Zhang, Y.X., Chao, Q.C., Zheng, Q.H. and Huang, L. (2017), "The withdrawal of the US from the Paris agreement and its impact on global climate change governance", Advances in Climate Change Research, Vol. 8 No. 4, pp. 213-219.

\section{Further reading}

Adams, M., Quinonez, P., Pallis, A.A. and Wakeman, T. (2009), "Environmental issues in port competitiveness", Working Paper, Dalhousie University.

Cahoon, S. and Hecker, R. (2005), "Seaports in the new economy: using services marketing strategies to increase cargo throughput in a hypercompetitive environment", Proceedings of the International Association of Maritime Economists Annual Conference, Limassol, 22-25 June.

CAAP (2010), "San Pedro Bay ports clean air action plan 2010 update", October 2010, p. 387, available at: www. cleanairactionplan.org/documents/2010-final-clean-air-actionplan-update.pdf/

ESPO (2019), ESPO Conference, Dublin, 1-2 June.

Lam, J.S.L. and Van de Voorde, E. (2012), "Green port strategy for sustainable growth and development”, Transport Logistics for Sustainable Growth at a New Level, International Forum on Shipping, Ports and Airports (IFSPA), pp. 27-30.

Lavissière, A. and Mandják, T. (2017), "Nested business network model: the network rubric's cube", Proceedings of the 33rd conference of the Industrial Marketing $\mathcal{E}$ Purchasing Group (IMP), Kuala Lumpur.

Powell, W.W. (1990), "Neither market nor hierarchy: network forms of organization", Research in Organizational Behavior, Vol. 12, pp. 295-336.

\section{Corresponding author}

Tibor Mandják can be contacted at: tmandjak@emnormandie.fr 


\section{AUTHOR QUERIES}

\section{AUTHOR PLEASE ANSWER ALL QUERIES}

AQau-Please confirm the given-names and surnames are identified properly by the colours.

=Given-Name, $=$ Surnam $\epsilon$ :

The colours are for proofing purposes only. The colours will not appear online or in print.

AQ1- Please note that following citations are missing from reference list. Please provide complete reference for:

Fedi and Lavissière, 201 ; orld Health Organization, 201 :-1 andják and Lavissière, 201 ebourg et al., 2016.=

AQ2 - Note that the following is unclear as given. Please revise for clarity: Its infrastructure such as roads was cut part. .

AQ3- Please provide complete reference for: Port of Los Angeles, 201 